\title{
Material Puncture/Hole
}

National Cancer Institute

\section{Source}

National Cancer Institute. Material Puncture/Hole. NCI Thesaurus. Code C62966.

Device material(s) punctured leading to undesired holes/openings. 